\title{
ISLAMIC FINANCE IN ETHIOPIA: CURRENT STATUS, PROSPECTS AND CHALLENGES
}

\author{
Suadiq Mehammed Hailu \\ PhD Candidate in Finance \\ Çukurova University, Adana, Turkey \\ E-mail:Suadiq1434@gmail.com \\ Dr. Nissar Ahmad Yatoo \\ Department of Islamic Economics Banking and Finance \\ International Open University, Tallinding, The Gambia \\ E-mail:yatoosiraj@gmail.com
}

\begin{abstract}
Ethiopia is a country found in the horn of Africa and notable in the Muslim world as the destination of the two migration of the companions of Prophet Muhammad (PBUH). Ethiopia has a Muslim population expected to be around 50 million. Unfortunately, with this significant Muslim population, it accommodates Islamic finance in its conventional financial system lately. This study aims to investigate the current status, prospects, and challenges of Islamic finance in Ethiopia. For these reasons, different secondary data were collected and analyzed. The result of the study indicated that Islamic finance in Ethiopia is representing by three financial institutions such as Islamic banks, Islamic Insurance and Islamic microfinance. Islamic banking is providing through the Interest-free banking window and fully-fledged forms of interest-free banking. The interestfree banking window system is adopted by conventional banks, whereas Full-fledged Islamic Banks providing services using their own separate Sharia-compliant financial system. The result also indicated that high public demand, adequate capital for the establishment, availability of substantial customers, easy deposit mobilization and profitability are the foremost opportunities for Islamic finance in Ethiopia. Whereas, negative perception about Islamic finance, legal framework challenges such as restriction of investment and double taxation, and lack of skilled human resources are the main potential hindrances for the sector.
\end{abstract}

Keywords: Ethiopia, Islamic Finance, Interest-Free Banking Window, Full-Fledged.

JEL Classification Codes: F65, G21, G22.

\section{INTRODUCTION}

The creator (Allah) sent down books for his messengers that govern human beings. He sent down Quran for his last messenger Prophet Muhammad (PBUH). Every activates of a Muslim is governed by an Islamic law called 'Shariah'. Ayub (2007) defined Sharia as "a code of law or divine injunctions that regulate the conduct of human beings in their individual and collective lives." Therefore, Islamic Sharia is not restricted by ruling the commonly knows five pillars of Islam such as Shahada (declaration faith), Salat (prayer), Zakat (almsgiving), Sawm (fasting) and 
Hajj (Pilgrimage); instead Islamic shariah encompasses the spiritual, social, economic and political aspects of human life (Iqbal \& Mirakhor, 2011).

Islamic Sharia has its own primary and secondary sources. The primary sources of Islamic sharia are Quran and Sunnah of the Prophet Muhammed (PBUH); whereas the secondary sources of Sharia are the consensus Muslim scholar (Ijmaa), analogy (Qiyas) and the intellectual effort of scholars (Ijtihad) (Philips, 2006; Ayub, 2007). Muslim scholars like Imam Al-Ghazali, Al- Shatbi and Tahir Ibne Ashoor explained the purpose of Islamic Shariah through detail studying of sharia sources (Auda, 2008; Ayub, 2007). The objectives of Sharia are categorized into primary and secondary objectives. The primary objectives of Islamic Sharia are s protection of religion, life, progeny, intellect and wealth. The Secondary purpose of Sharia includes launch fairness and equality; encouragement of mutual help, social security and solidarity; preserving peace and safety; collaboration in encouraging goodness and prevention of evil actions; and promoting in keeping global moral values (Nyazee, 2016; Ayub, 2007; Auda, 2008).

The position of Islamic economics and finance is explained by Muslim scholars and Islamic institutions. Regarding the place of economics and finance in Islam, Iqbal and Mirakhor (2011) explained that Islamic thought can be classified into three main sets such as faith (aqidah), law (shariah), and moral and ethics (akhlaq). Faith (aqidah) explains the relationship among the creator (Allah) human beings, meaning that regarding faithfulness and beliefs. On the other hand, morals and ethics (akhlaq) govern the conduct, attitude, and morals of Muslims in society. The overall daily practices and actions of a Muslim are explained by Islamic law (shariah). Shariah is also categorized into two subsets of practices and actions such as Man-to God worship (Ibadat) and Man-to-man activities (Muamalat). Muamalat describes the social, economic and political conducts of a Muslim. Accordingly, the rulings regarding economics and financial activates are among the significant sets of Muamalat.

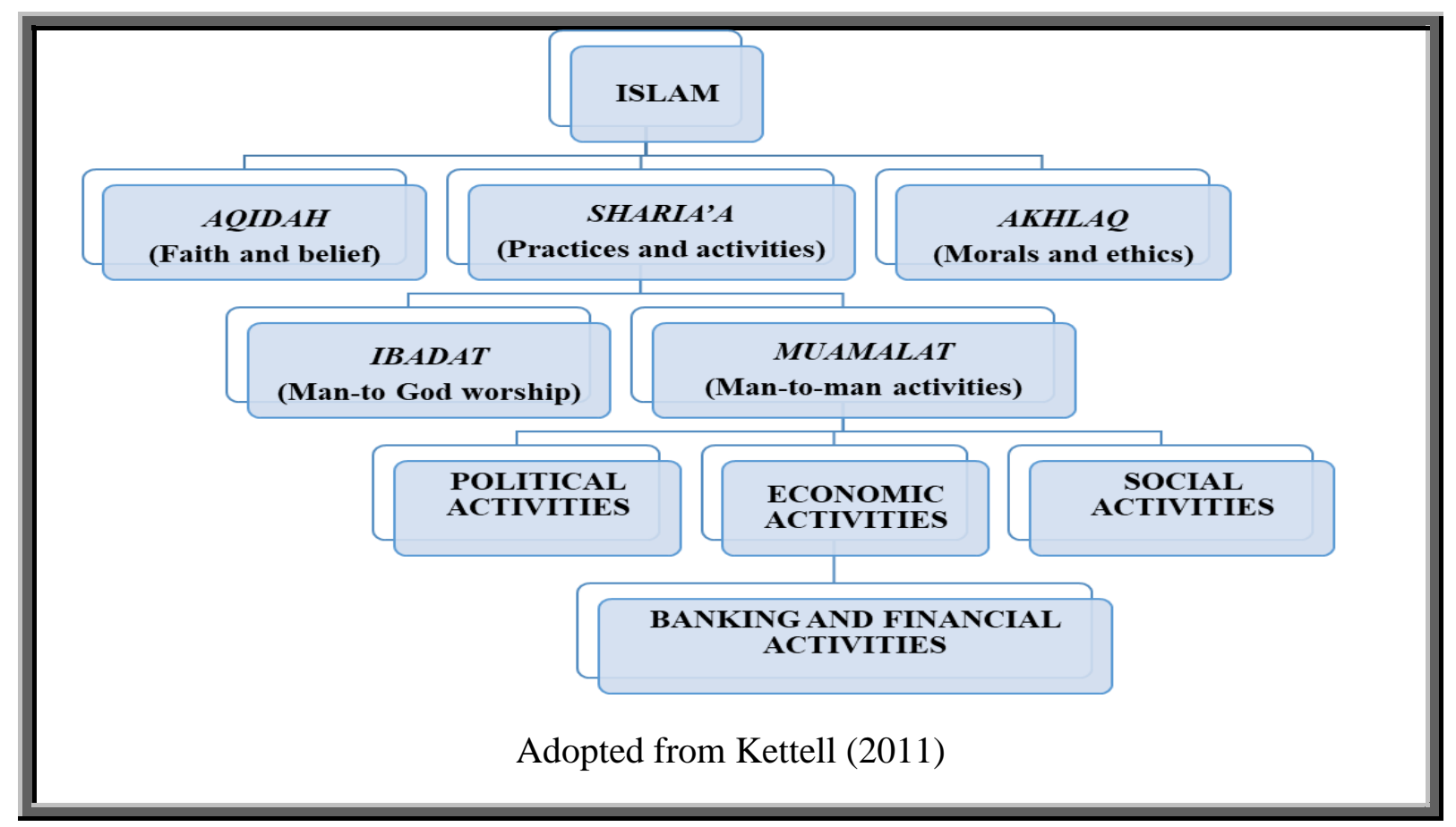

Figure 1. The Position of Economics and Finance in Islam 


\section{The Synopsis Islamic Finance Development}

Islamic finance practices have been applied from the era of Prophet Muhammed (PBUH). Alharbi (2015) stated that:

"The origin of Islamic finance dates back to the dawn of Islam 1,400 years ago. Historical books written during the early years of Islam indicated that during the 1stcentury of Islam (AD 600), some forms of banking activities existed that were similar to modern banking transactions. Furthermore, these ancient books revealed that Al-Zubair bin Al-Awam, one of the most famous personalities in Islam, was accepting deposits from people as loans and investing that money. At the time of his death, his debt had reached 2,200,000 dinars, as counted by his son Abdullah." (PP: 12)

This indicated that Islamic finance practices are ancient as Islam itself. As stated by Chachi (2005), Muslims have established their interest-free financial system for resource mobilization and to invest it for productive business and end-user needs from the early era of Prophet Muhammed (PBUH). They were applying Islamic finance practice through "profit and loss sharing modes" of Mudarabah (a form of partnership in which one individual gives capital and the other party effort) and Musharakah (a form of partnership in which two or more individuals or institutions contribute capital effort).

Among the Islamic finance products and services were applied by Muslims in the early age of Islam are banks, byta al-mal (the treasury of Islamic state), money order, bill of exchange, accepting the deposit, and using of the cheque are common examples (Chachi, 2005; Mohamad, Abdullah, Mohamad, \& Abidin, 2013; Alharabi, 2015). For instance, byta al-mal (the treasury of Islamic state) was performed as a central bank of a state by collecting income from Zakat, land tax, donation and ownerless properties and supporting the needy community from the collected income. Abdullah bin Zubayr, the companion of Prophet (PUBH), once collect money from the people of Mecca and he wrote an approval letter to his brother in Iraq, where the possessor of the letter can take his money there (Mohamad, et al., 2013). After reviewing several historical writings, Chachi (2005) stated that that "there were indeed bankers called sarraffeen or sayarifah or jahabidhah and banks called dawawin al-jahabidhah." (PP:10)

As time goes through, the Muslim world vanished its technological and economic advancement due to deviation from Shariah principles, extravagance, lack of organizational culture, political failure, and several wars with crusaders, Mongols and Tatars. Due to these reasons, financial institutions which provide services based on Shariah principles were replaced by interest-based western financial institutions (Chachi, 2005). During the time of the Ottoman Empire (1301-1922), there were limited Sharia-based financial products and services. Siddiqi, one of the famous economists defined the Ottoman Empire period as "stagnation took the Muslim mind in its grip" (Islahi, 2007). In this era, most financial products and services were provided by nonMuslim minorities such as Greeks, Armenians, Jews and Levantines (Agoston and Masters, 2008).

In the 19th century, almost all Muslim countries adopted interest-based western financial systems. Considering this, Nassir, cited in Alharabi (2015) stated that when the western banking system is practiced in all Muslim countries, three main opinions are provided by Muslim scholars. According to the first opinion accessing products and services providing by conventional financial institutions is halal (permitted) as we do not have a Shariah-compliant financial system. On the other hand, the proponent of the second opinion stated that accessing conventional financial services is haram (prohibited), but financial services are important to the day to day lives of the community. Accordingly, they also permitted accessing conventional financial services and products. On contrary, the supporter of the third opinion stated that interest-based financial 
services and products are prohibited in Islam, however, Islam has different types of contracts which can be applied in the finance practice without interest. Therefore, they said that it is possible to establish Sharia-compliant financial institutions. Finally, the opinion of the third group gain acceptance from Muslim scholars and the idea of establishing interest-free financial institutions gained momentum as a theory in the 1940s. These were the turning points to the commencement of modern Islamic finance.

\section{The Commencements of Modern Islamic Finance}

Following a long period of dominance by conventional finance throughout the world, the Shariacompliant Islamic finance system engaged in the finance industry as an alternative to those who are not accessing conventional finance due to religious reasons (Tiby \& Grais, 2015). According to Alharabi (2015), the development of modern Islamic finance can be categorized into three stages. The first stage covers from 1930-1963 and during this period the establishment of Shariacompliant financial institutions was under theoretical work by scholars. The second stage is known as the introduction and establishment period of Sharia-compliant financial institutions. This stage covers the period from 1963-1976. In this stage, the first attempts were made to established Shariacompliant banks in Pakistan and Egypt in 1950 and 1963 respectively. In this stage, several conferences were carried out on Islamic finance in the middle east. The third stage of the development of modern Islamic finance is called the spread of Islamic finance across the globe. This stage covers the period from 1997 to the present. During this period several Islamic Finance Institutions are established and continuing establishing around the world.

Currently, Islamic finance is expanding in all Muslim and non-Muslim countries as an alternative to the conventional financial system. Nagaoka (2012) indicated that Islamic finance is growing quickly after the year 2000 due to the commencement of new Islamic financial products like "Sukuk, commodity Murabaha and Islamic derivative." Islamic Shariah has several contracts which are playing a significant role in developing Sharia-compliant financial products and services.

\section{Principles of Islamic Finance}

As previously explained in this paper, every activity of a Muslim should compliant with Shariah principles. Considering the day to day financial activities of a Muslim, scholars have drawn principles for Islamic finance from the Quran and Sunnah. "Prohibition of interest (riba) and permission of trade, avoiding Gaharar, avoiding gambling and game of Chance, profit and loss sharing, the requirement of Zakat and avoiding participation in prohibited investment" are the basic principles of Islamic finance (Ayub, 2007; Ökte, 2010; Uddin, 2015).

\section{Islamic financial Institutions and Their products and Services}

Sharia-compliant financial services are provided by different financial institutions. The common Islamic financial institutions are Islamic Banking, Islamic Capital Markets, Takāful (Insurance) and Islamic microfinance institutions.

Islamic banking is a financial institution providing banking services following the Islamic Shariah principle. Islamic banking is a deposit-taking institution without paying interest on collected deposits (Shanmugan \& Zahari, 2009). Researchers in this area tried to categorized products and services provided by Islamic banking. The classification of Obaidullah (2005) is presented in the following table. 
Table 2. Types of Islamic Banking products and services

\begin{tabular}{|c|c|c|}
\hline FI & Types of Products/Services & Products/ Services \\
\hline \multirow[b]{5}{*}{ 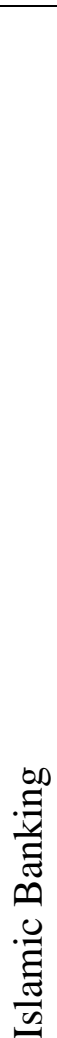 } & Deposits Services & Current deposit, Saving deposit, Investment deposits \\
\hline & Retail/Consumer Banking & $\begin{array}{l}\text { Housing and Property finance, Hire Purchase, Share } \\
\text { Financing, working capital Financing, Credit and Charge } \\
\text { card. }\end{array}$ \\
\hline & $\begin{array}{l}\text { Corporate } \quad \text { Banking/Trade } \\
\text { Finance }\end{array}$ & $\begin{array}{l}\text { Project Financing, Letter of Credit, Venture Capital, } \\
\text { Financing Syndication, Revolving Financing, Short-term } \\
\text { Cash Advance, Working Capital Finance, Letter of } \\
\text { Guarantee, Leasing, Export/Import finance, Construction, } \\
\text { Bill Discounting and Underwriting and Advisory service. }\end{array}$ \\
\hline & $\begin{array}{l}\text { Treasury/Money Market } \\
\text { Investment Products }\end{array}$ & $\begin{array}{l}\text { Sell and buy-back agreement, Islamic Bond, Government } \\
\text { Investment Issues }\end{array}$ \\
\hline & Other Products and Services & $\begin{array}{l}\text { Stock-Broking Service, Fund Transfer (Domestic and } \\
\text { Foreign), Safe-keeping and Collection (Negotiable } \\
\text { Instruments), Factoring, Administration of Property, } \\
\text { hiring of storage Boxes, Demand Draft, Traveler's } \\
\text { Cheques, ATM services, Standing Instruments, } \\
\text { Telebanking. }\end{array}$ \\
\hline
\end{tabular}

Conventional insurance products and services are prohibited in Islam because of they engaged in activities against Shariah principles such as interest, gambling, risk probability and uncertainty (Afzal-ur-Rahman,1974). As stated by Obaidullah (2005), Swartz and Coetzer (2010), Htay and Zaharin (2012); and Pasha and Hussain (2013), takaful is providing through three main models. These modes are summarized as follows.

Table 3. Models of Islamic Insurance

\begin{tabular}{|c|c|c|}
\hline FI & Models of Takaful & Explanation \\
\hline \multirow{3}{*}{ 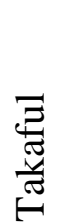 } & Tabarru Model & Based on member's donation (Tabarru) to the Takful fund \\
\hline & Mudaraba Model & Members and workers go into in a Mudarabah agreement \\
\hline & Wakala Model & Takaful agents acts as a representative for the members \\
\hline
\end{tabular}

Microfinance institutions aimed to provide financial services for the poor and for those who cannot access financial services from other financial institutions. As other conventional financial institutions, traditional microfinance institutions are providing interest-based products/services. Therefore, Sharia-compliant microfinance products and services are developed to provide financial services/products to unbanked and poor societies (Dhaoui, 2015). Islamic 
Microfinance institutions are providing products and services through two models such as nonprofit models and profit-based models. Nonprofit models of Islamic microfinance engaged in collecting and paying Zaka, receiving and managing awqaf (donation), and collection of Qard Hasan (benevolent loan). On the other hand, Profit based Islamic microfinance institutions providing interest-free products/ services like micro-Saving, micro-Credit and micro-equity (Obaidullah, 2008).

Islamic Capital markets products are playing a significant role in the development of the Islamic financial system. Alam, Gupta, and Shanmugam (2017) defined the Islamic capital market as follows: "Islamic Capital Market (ICM) is an integral part of Islamic Financial System where Syariah compliant financial assets are transacted. It plays a pivotal role in the growth of Islamic Financial Institutions. It is a market where people, companies, and governments with surplus funds transfer it to people, companies, or governments who have a shortage of funds. It acts as a financial intermediary by channelling money from surplus to deficit unit." (PP:397)

Alam, Gupta and Shanmugam (2017) classified Islamic capital market products into three categories such as Islamic equity market and related products, Islamic fixed-income instruments (Sukuk) and Islamic-structured products and derivatives.

Currently, Islamic finance is flourishing in all corners of the globe in Muslim and nonMuslim countries as an alternative to the conventional financial system. According to the 2020 Islamic Financial Services Board (IFSB) Islamic Financial Services Industry Stability Report, the global growth rate of Islamic finance was estimated at $11.4 \%$ and the total wealth of the global Islamic finance industry was $\$ 2.44$ trillion by the end of 2019. The 2020 Global Islamic Finance Report (GIFR) also estimated the global wealth of the Islamic finance industry as about \$2.73 trillion. From the total wealth of global Islamic finance; Islamic Banking, Sukuk, Islamic fund, takaful and Islamic microfinance covers $74 \%, 17 \%, 4 \%, 2 \%$ and $1 \%$ respectively (GIFR,2020). Therefore, most of the global Islamic finance wealth is concentrated in the Islamic banking sector.

\section{Statement of The Problem}

The expansion of the Islamic finance industry to all corners of the world is continuously increasing as an alternative financial system for those who are not accessed conventional finance. The growth and wealth of global Islamic finance are blooming year to year. The global Islamic finance wealth is dominantly owned by Gulf Cooperation Council (GCC), South-East Asia, Middle East and South Asia countries. Islamic Finance Industry in Africa is still at the infant level, and its share from global Islamic finance is about $1.6 \%$ (IFSB, 2020).

From Africa, Ethiopia is one of the countries that integrate Islamic finance with its financial system lately. Ethiopia has a dominant Muslim society that needs Sharia Compliant Islamic financial products /services. Ethiopia Muslims were asking the government to establish Shariahcompliant Islamic finance institutions for more than 15 years. In 2007, the representative from the Muslim Diaspora community present an official request for the late prime minister of Ethiopia to establish a Sharia-compliant bank. After a long time of struggle by Ethiopian Muslims, the establishment of full-fledged Islamic banking is permitted in May 2020. In terms of the numbers of the Muslim population, Ethiopia has a substantial Muslim population more than most countries that are leading in the Islamic finance industry. Therefore, this study aims to assess the current status of Islamic finance in Ethiopia and to identify the prospects and challenges of Islamic finance in Ethiopia. 


\section{Significance of the Study}

Through presenting and identifying the current status, prospects and challenges of Islamic finance, this paper will help policymakers to develop demand-driven policy which insure conducive Islamic finance practice in Ethiopia. Furthermore, due to the absence of adequate research on this topic in Ethiopia, this paper will add value to the literature on this topic.

\section{Objectives of The Study}

- Assess the current status of Islamic finance in Ethiopia.

- Identifying the main opportunities for the expansion of Islamic Finance in Ethiopia.

- Investigate the main challenges for the expansion of Islamic Finance in Ethiopia.

\section{Research Questions}

This research is aiming to answer the following questions.

- How is the current status of Islamic finance in Ethiopia?

- What are the main prospects of Islamic finance in Ethiopia?

- What are the main challenges of Islamic finance in Ethiopia?

\section{Organization of the Paper}

This study encompasses five chapters. In the first chapter; the historical background of Islamic finance, statement of the problem, the significance of the study, research question and organization of the paper are described. Related literature regarding the prospects and challenges of Islamic finance are depicted in chapter two. Chapter three is given to explain the research methodology. The collected data are presented and analyzed in Chapter four. Finally, in chapter five conclusion and recommendation are explained.

\section{LITERATURE REVIEW}

In this chapter studies conducted to assess the prospects and challenges of Islamic finance are summarized. In the first section, prospects and challenges of Islamic finance are illustrated in general and in the second section studies related to prospects and challenges of Islamic finance in Ethiopia are reviewed.

In the early development stage of Islamic finance; Iqbal, Ahmad, and Khan (1998) assessed the challenges facing the Islamic finance industry. They classified challenges into two subcategories such as challenges related to institutional aspects and challenges related to operational aspects. Challenges related to institutional aspects are lack of proper organized legal framework, lack of suitable legal and accommodating policies, unavailability of accounting standards, lack of equity institutions, and absence of a secondary market for Islamic finance products. On the other hand, they stated that operational relation challenges are shortage of financial engineering; issues on Sharia principles; lack of teaching, training, research and development institutions; shortage of profit-sharing financial sources; insufficient deposit mobilization; computation and globalization.

Despite the expansion and development of Islamic finance, challenges are facing the sector. Malaysia International Islamic Finance Center -MIFC (2015) explained the driving forces for growing Islamic finance even in Europe. The increase of trade and financial transaction between OIC countries and the EU, the expansion of choosing ethical financial services and products, the growth of the halal food sector, the need for liquid assets and the support from the government to the Islamic finance sector are among the potential prospects for the growth of Islamic finance in Europe. On the other hand, MIFC (2015) stated that standardization and harmonization (different 
interpretations for Islamic financial laws), human capital issues (shortage of Islamic finance professionals), Sharai requirement and existing legal frameworks (challenges to harmonize the Sharia and existing laws), and public awareness (lack of public awareness about Islamic finance products and services) are among the potential challenges facing Islamic Finance Industry.

Karimi (2007) also identified the legal framework problems facing Islamic banking such as an absence of Islamic finance court to solve disputes regarding Islamic finance, the need for amendment for existing commercial law of countries to accommodate Islamic finance in the system, the need for a new form of financial statements, lack of effective prudential Islamic finance regulation and lack of a standard for products and services.

The challenges facing the Islamic finance industry is different from country to country due to their previously applied business and commerce law. According to Karbhari, Naser, and Shahin (2004), the challenges facing Islamic finance in the west in which predominantly applied conventional financial system are lack of standardization, shortage of appropriate regulation and legislation, inability to fulfil the western capital and liquidity requirements criteria, discrimination by tax, unavailability of adequate financial instruments, the need for a separate accounting sundered, lack of liquid financial instruments, lack of qualified human resource, insufficient marketing and computation form conventional counterparts.

Further, Mohd Zamil (2014) investigated the problems and challenges facing the Islamic finance industry in Malaysia using semi-structured interviews for selected respondents such as Sharia committee, Shariah officer and Chief Executive Officers. The finding of his study indicated that "dual-banking environment, lack of support from the regulatory framework related to products and services, Shariah non-compliance, operation and management, lack of expertise in human capital, lack of accountability, and lack of influence of accounting practices and auditing" are identified as the main problems and challenges facing Islamic finance in Malaysia.

To sum up, the above-mentioned studies indicated that lack of standardization, lack of appropriate legal framework, shortage of experts and scholars in Islamic finance, unavailability of adequate financial instruments, the need for a separate accounting sundered, lack of liquid financial instruments, computation form conventional counterparts and lack of public awareness about Islamic finance products and services are the main challenges facing Islamic finance in general.

When we come to assess the prospects and challenges of Islamic finance in Ethiopia, there are not enough studies conducted due to the sector is permitted in Ethiopia lately. However, even within the short time, some researchers conducted to show the prospects and challenges of Islamic finance in Ethiopia.

Hailu, Kapusuzoglu, and Ceylan (2019) assessed the role of Islamic financial products in the reduction of financial exclusion in Ethiopia. Their finding indicated that most of the Muslim communities' reasons for not accessing conventional finance were religious reasons - meaning that the absence of Shariah-compliant financial institutions. Furthermore, their finding also shows there was high interest and potential to establish and access Sharia-compliant financial services in Ethiopia. To examine the role of

Islamic finance to promote small and medium enterprises in Ethiopia, Ali, Bushera, and Yesuf (2020) conducted a study and they stated that to maximize the role of Islamic finance to promote Small and medium enterprises, suitable regulatory framework, organize financial infrastructure, developing public awareness and producing skilled human resource should get appropriate attention from all stakeholders.

Belayneh (2020) was surveyed to examine the opportunities and chillness of Islamic finance in Ethiopia. High public demand and attracting new investors are among the main 
potentials of Islamic finance in Ethiopia. On the other hand, lack of skilled manpower, unavailability of the capital market, lack of public awareness and negative perception abut Islamic finance are among the main challenges facing the development of Islamic Finance in Ethiopia. Ali (2020) also investigated the challenges facing Islamic microfinance institutions in Ethiopia. He points out that the challenges facing Islamic microfinance in Ethiopia are "unavailability of clear and detailed legislation from the regulator National Bank of Ethiopia (NBE), shortage of trained and knowledgeable workforce related to interest-free microfinance services, immense and arduous administrative cost of the system and clients' nonconformity with some Sharia principles like failure to deliver the item to the institution after they acquired it from the market on behalf the microfinance institutions."

Islamic banking is providing products and services for customers through three establishment ways such as full-fledged Islamic banking, Islamic window and Islamic subsidiaries banks (Sole, 2007 and Abedifar, Ebrahim, Molyneux, \& Tarazi,2015). Considering this, Abdulhade (2020) studied the opportunities and challenges facing Interest-free window Banking in Ethiopia. The result of the study indicated that high demand for products and services and the capability of collecting more deposits through Islamic banking products and services are among the opportunities for Interest-free window banking in Ethiopia. On the contrary, computation with other banks providing Islamic banking services through window system, lack of knowledge about Islamic banking products and lack of skilled human resources are identified as the main challenges facing interest-free window practice in Ethiopia.

Concerning the newly permitted full-fledged Islamic banking in Ethiopia, Aman, Ali, and Yesuf (2021) assessed the basic failure or success factors for full-fledged Islamic banking in Ethiopia. Their finding shows that legal, monitoring and institutional background; skilled human resources; reputation and public image; qualities and quantities of providing services and products, standardize Shariah ruling; central Sharia compliance supervisory institution; and computation are among the main factors which may decide the fate of full-fledged Islamic banking in Ethiopia.

Hailu and Bushera (2020) also assessed the opportunities and challenges of Islamic banking in Ethiopia through detailed qualitative analysis. They stated that the availability of unbanked vast customers, high demand and the capability of mobilizing adequate capital and deposit are among the main prospects. While misconception about Islamic finance, legal and regulatory framework challenges, limitation of banks investment participation, double taxation, unavailability of the central supervisory body and lack of skilled human resource are the main challenges facing the newly permitted fulfilled Islamic Banking in Ethiopia.

In general, the reviewed literature shows that the newly permitted full-fledged Islamic banking in Ethiopia is facing the same challenges which are facing the global Islamic finance industry. Legal and regulatory problems, unavailability of contorting mechanisms and lack of skilled human resources are the main challenges facing Islamic finance in Ethiopia.

\section{RESEARCH METHODOLOGY}

Islamic financial system is accommodated in the Ethiopian financial system lately. Initially, offering Islamic banking products and services by conventional banking through a separate window is permitted and finally, establishing full-fledged Islamic finance institutions are permitted in late 2020. Hence, this study aims to assess the current status, prospects and challenges of Islamic finance in Ethiopia.

To assess the current status, prospects and challenges of Islamic finance in Ethiopia; a qualitative research method is applied. There are different types of data collection methods in qualitative research method such as observation, analysis of secondary data and interview 
(Gill,2008). Therefore, to achieve the objective of this study different types of secondary data sources such as previous studies, reports, news, magazines from different sources are collected. The available information from the website of the National Bank of Ethiopia and other commercial banks are also collected and analyzed.

\section{ANALYSIS}

This study is trying to archive three basic research objectives such as presenting the current status of Islamic finance in Ethiopia, assessing the main opportunities for the expansion of Islamic Finance in Ethiopia and assessing the main challenges for the expansion of Islamic Finance in Ethiopia. Using the collected secondary data, the three research questions are answered and explained in the following sections.

\section{Current Status of Islamic Finance in Ethiopia}

Ethiopia has a special place in Islam as it accepts Muslim migrants from Mecca two times and It also among the countries Islam reached early, next to Mecca. Currently, the population of Ethiopia is expected to be around 110 million and half of it is expected to follow Islam. When we come to accessing financial services in Ethiopia, in 2017 only 38\% yang population have a bank account. This indicated that about $62 \%$ young population do not accuse the basic bank account (DemirgüçKunt, Leora, Dorothe, Saniya, \& Jake, 2018). According to the study conducted by Hailu, Kapusuzoglu and Ceylan (2019) religious reason was among the main factors that affect access to conventional financial services.

As Ethiopia has a substantial Muslim population and high demand for Sharia-compliant financial products and services, Ethiopian Muslims was asking permission from Islamic finance in Ethiopia for a long period. After a long period of informal requests for the Ethiopian government, in 2007, a group of Muslims representing the Ethiopian Muslim Diaspora present several questions for the late Prime Minister of Ethiopia. One of the basic questions asked by Diaspora representatives was the permission of Islamic banking in Ethiopia (Feyissa, 2012). Then, in 2008, a group of Muslims who has an imitation to establish Islamic banking in Ethiopia called "Zam-zam bank" presented the importance of establishing Islamic banking in Ethiopia for late Prime Minister Meles Zenawi.

After discussion, the Prime Minister informed the governor of the National bank of Ethiopia (NBE) to prepare a directive that permits the formation of Islamic Banking in Ethiopia (Al-Hashimi, 2012). Following the high demand for Islamic financial products and services, in 2008, NBE revise the "Licensing and Supervision of Banking Business" proclamation and issued a new proclamation that creates room for establishing Islamic financial institutions. The new proclamation is called Proclamation is called "Proclamation No. 592/2008" and in this proclamation Article 22, Sub-article 2 states "The National Bank may issue a directive to regulate banking businesses related to non-interest-bearing deposit mobilization and fund utilization." This is the turning point for Islamic finance history in Ethiopia.

Following the release of proclamation No. 592/2008: Article 22, Sub-article 2, all conventional commercial banks in Ethiopia started providing interest-free current account deposit services. On the other hand, the organizers of Zam Zam bank was started selling the share to establish full-fledged Islamic banking and they could 137 million Birr within four months. In that time the minimum paid-up capital to establish a bank in Ethiopia was 75 million Birr (Zam-zam Bank, 2012). This outstanding performance indicated that the high demand for Islamic finance in Ethiopia.

After a long effort to establish the first Interest-free banking in Ethiopia, unfortunately, the National Bank of Ethiopia issued a new direction that blocks the ways of establishing full-fledged 
Islamic finance in Ethiopia. The new directive is known as "Directives to Authorize the Business of Interest-Free Banking No. SBB/51/2011." In this Directive article 2(2) define interest-free banking business as "a banking business in which mobilizing or advancing funds is undertaken in a manner consistent with Islamic finance principles and mode of operation that avoids receiving or paying interest" and article 2(3) states "interest-free banking window refers to a unit within a conventional bank exclusively offering interest-free banking services." Article 2(3) indicated that only conventional banks can offer interest-free banking services through a separate window.

Because of Directive No. SBB/51/2011, the ways of establishing full-fledged Islamic banking in Ethiopia is closed and finally, on January 11, 2012, the National Bank of Ethiopia informed the organizers of Zam Zam bank either to establish a conventional bank that can offer interest-free through window system or terminate the establishment process. The main objective of Zam zam bank organizers is to provide alternative Sharia-compliant financial services for those who are not accessing conventional financial serviced due to religious reasons. Therefore, they were not accepting the offer from NBE to establish a conventional bank and in May 2012 the establishment process of Zam zam bank was terminated by refunding the money to shareholders (Zam-zam Bank, 2012).

After the issuance of Directive No. SBB/51/2011, conventional banks started providing interest-free banking services through a separate window. This system is called the Interest Free Banking window (IFB window). Conventional Banks started providing IFB window and the year of started providing IFB window services are summarized in the following table.

Table 4. History of IFB window in Ethiopia

\begin{tabular}{|l|l|l|l|}
\hline No. & Name of Conventional Banks & $\begin{array}{l}\text { Year of } \\
\text { Establishment }\end{array}$ & $\begin{array}{l}\text { IFB Window } \\
\text { Starting year }\end{array}$ \\
\hline 1 & Commercial Bank of Ethiopia (CBE) & 1963 & 2013 \\
\hline 2 & Oromia International Bank (OIB) & 2008 & 2013 \\
\hline 3 & United Bank (UB) & 1998 & 2014 \\
\hline 4 & Wegagen Bank (WB) & 1997 & 2015 \\
\hline 5 & Nib Bank (NB) & 1999 & 2015 \\
\hline 6 & Cooperative Bank of Oromia (CBO) & 2004 & 2015 \\
\hline 7 & Abay Bank (AbB) & 2010 & 2016 \\
\hline 8 & Awash Bank (AwB) & 1995 & 2016 \\
\hline 8 & Wegagen Bank (WB) & 1997 & 2016 \\
\hline 9 & Abyssinia Bank (AB) & 1996 & 2017 \\
\hline 10 & Dashen Bank (DB) & 1995 & 2018 \\
\hline 11 & Buna International Bank (BIB) & 2009 & 2019 \\
\hline 12 & Debub Global Bank (DGB) & 2012 & 2021 \\
\hline
\end{tabular}

Source: Collected from Each Bank's website

Even though conventional banks started providing interest-free banking services through window system Muslims are not satisfied due to the services is providing by the capital and 
infrastructure of the conventional bank. According to the study conducted by Hailu, Kapusuzoglu and Ceylan (2019) Muslims are not satisfied with the interest-free window practice because the service is providing by interest-based conventional banks. Therefore, Muslims are continually asking the government to permit the establishment of full-fledged Islamic finance institutions. Finally, after seven years of exclusive IFB window practice in Ethiopia, the current prime minister of Ethiopia, Abiy Ahmed vowed to permit the establishment of full-fledged interest-free financial intuitions on May 22, 2019 (Getachew \& Kedir, 2019).

Following the promise made by Dr. Abiy Ahmed, the National Bank of Ethiopia issued a new proclamation known as "Proclamation No: 1159/2019". The new proclamation permits the establishment of full-fledged Islamic banking in Ethiopia. Article 59(1) of this proclamation states "Without prejudice to the requirements of specified under the provisions of the proclamation, the National Bank may issue a Directive to prescribe additional conditions of licensing, supervision and requirements to establish Interest-Free Bank. For this sub-article, Interest-Free Bank means a company licensed by National Bank to undertake only interest-free banking business."

After the release of Proclamation No. 1159/2019, the initiation to establish several fullfledged Islamic banks, Islamic Insurances and Islamic microfinance institutions started. Zam Zam, Hijira, Nejashi, kush and Huda are among the banks start selling the share to the public to establish full-flagged Islamic Banking. Currently, as of July 2021, Zam Zam and Hijira banks are received an operational license from the National Bank of Ethiopia and Zam Zam Bank officials started providing services.

The establishment initiation of Islamic financial institutions in Ethiopia is not only in the banking sector. However, interest-free microfinance institutions are operating in Ethiopia without adequate legal firework. According to Ali (2020), The following microfinance institutions are providing sharia-compliant microfinance services in the Muslim dominated areas of Ethiopia.

Table 5. Interest free Microfinance Institutions in Ethiopia

\begin{tabular}{|l|l|l|}
\hline No. & Name Islamic MFI & Establishment Year \\
\hline 1 & Harar Microfinance Institution (HMFI) & 2014 \\
\hline 2 & Dire Micro Finance Institution (DMI) & 2013 \\
\hline 3 & Somali Microfinance Institution (SMFI) & 2012 \\
\hline 4 & Rays Microfinance Institution (RMFI) & 2014 \\
\hline
\end{tabular}

Source: Ali (2020)

After the 2019 proclamation that permits the establishment of full-fledged Islamic financial institutions, there are some imitations to establish Islamic microfinance institutions in all corners of Ethiopia. Regarding Islamic Insurance in Ethiopia, Global Insurance Company the first company in providing Islamic insurance services in Ethiopia. According to Capital Newspaper, two new companies are asking for licenses to provide Islamic Insurance services. To summarize, the current status of Islamic finance in Ethiopia is composed of IFB window, fulfilled Islamic banking, Islamic Insurance and Islamic microfinance institutions.

\section{Prospects of Islamic Finance in Ethiopia}

Taking into account the availability of risk in any investment, Islamic finance in Ethiopia have a good opportunity and potential. After reviewing different data, the main opportunities of Islamic 
finance in Ethiopia are high public demand, adequate capital for the establishment, availability of substantial customers, and easy deposit mobilization and profitability.

The first potential opportunity for the Islamic finance industry is the availability of huge possible customers for Islamic finance products and services. As stated previously, half of the Ethiopian population are expected to practice Islam. This means about 50 million Muslims are available in Ethiopia. This number of the Muslim population is more than most of the Muslim countries that applied Islamic finance. However, it is also expected non-Muslim communities who are interested in ethical finance may also access Islamic finance products and services.

The second potential prospect for Islamic finance in Ethiopia is a strong demand for Islamic finance products and services. The effort of Ethiopia Muslims asking the government since 2007, the establishment process of Zam Zam Bank from 2008-2011 and other serves indicted that there is a high demand for Islamic finance in Ethiopia. According to the survey conducted by Hailu, Kapusuzoglu and Ceylan (2019) in Addis Ababa, the capital city of Ethiopia, from the total respondents, about $97 \%$ stated that if full-fledged Islamic finance in Ethiopia is permitted, the will be either a customer or a shareholder in the fulfilled Islamic finance institution. Aman (2019) also stated that an increase of IFB window in Ethiopia indicated that there is a need for products and services.

The availability of abundant capital to establish full-fledged Islamic Financial Institutions is one of the prospects for Islamic finance in Ethiopia. As stated early, the ability to collect 137 million Birr within four months by Zam Zam bank in 2011, when the minimum paid-up capital to establish a bank in Ethiopia was 75 million Birr indicated that there is adequate capital for this sector.

Profitability and easily deposit mobilization also among the potential prospects of Islamic finance in Ethiopia. According to the Data collected from the National Bank of Ethiopia, as of September 30,202, the total deposit collected by all conventional IFB windows was about 66.5 Billion Birr. This indicated that full-fledged Islamic banks can mobilize deposits easily. Hailu and Bushera (2020) stated that the growth of IFB Window deposit mobilization from 2018 to 2019 Commercial Bank of Ethiopia (CBE), Cooperative Bank of Oromia (CBO) and Oromia International Bank (OIB) was $78.57 \%, 125.23 \%$ and $38 \%$ respectively. The growth of profit from 2018 to 2019 for the Cooperative Bank of Oromia (CBO) was 281\%. Therefore, this highest rate of growth in deposit mobilization and profit indicates a good prospect for full-fledged interest-free Banking in Ethiopia.

\section{Challenges of Islamic Finance in Ethiopia}

Even though there are promising opportunities for Islamic finance in Ethiopia, they are also potential challenges facing the Islamic finance industry. After reviewing available sources of data, the main challenges facing Islamic finance in Ethiopia are negative perception about Islamic finance from non-Muslim communities, legal framework challenges and lack of skilled human resources.

The global propaganda on Islam also affected the expansion of Islamic finance. In Ethiopia, some non-Muslim scholars are not supporting Islamic finance. They tried to explain the negative perception like if Muslims are open their bank, other religious followers may ask to establish their bank and It may result in the division of financial system. To assess the perception toward Islamic finance, Hailu and Bushera (2020) analyzed the comments on the news about the permission of full-fledged Islamic banking in Ethiopia. The result indicated that there was a substantial reflection of negative perception about Islamic finance. 
The main and significant challenges of Islamic finance is coming from the commercial code of Ethiopia-legal framework challenges. The commercial code of Ethiopia is an interestbased commercial code and when an interest-free financial system is permitted the is a need for amendment for some proclamations. For instance, in the banking business proclamation Directive No. SBB/60/2015 article 4 (4) states "A bank may hold up to $10 \%$ equity shares in a single nonbanking business other than insurance business" and article 4 (6) also stated that "A bank's aggregate equity investment in all non-bank business, including insurance companies, shall not exceed $10 \%$ of its net worth". Therefore, if this directive applies to Islamic banking, they cannot don any Mudaraba and Musharekah businesses. Considering this point, Sefiani (2014) indicated that "these articles create a conflict for issuing Musharaka or a Mudaraba partnership agreement in which a bank could own up to $100 \%$ of a business/transaction at the time of the signing of the contract". Murabahah (Cost-Plus-Profit Sale) is one of the primary products providing by Islamic Banks. According to this transaction, a customer requests a specified product and then the bank by and own that product. Finally, the bank sells the product to its customer accord.

\section{CONCLUSION}

The main of this study is to assess the current status of Islamic finance in Ethiopia and to identify the prospects and challenges of Islamic finance in Ethiopia. Considering the current status of Islamic finance in Ethiopia, there are three types of Islamic financial institutions in Ethiopia such as Islamic banking, Islamic insurance and Islamic Microfinance Institutions. From $2011-2019$ Islamic banking products and services were provided by the IFB window system. There are 12 conventional commercial banks in Ethiopia offering Islamic banking products through the IFB window system. In late 2019, establishing full-fledged Islamic banking in Ethiopia was permitted and more than 5 new Islamic banks started selling shares to the public. Among the formation Islamic banks, Zam Zam and Hjira banks are received an operational license from the National Bank of Ethiopia and Zam Zam Bank is started providing services in Addis Ababa and opening branches in all directions of the country is continued.

In the same way of any type of business, there are opportunities and challenges for Islamic finance in Ethiopia. The potential opportunities of Islamic finance in Ethiopia are high public demand, adequate capital for the establishment, availability of substantial customers, and easy deposit mobilization and profitability. While, the potential challenges are negative perceptions about Islamic finance from non-Muslim communities, legal framework challenges and lack of skilled human resources.

\section{REFERENCES}

Abdulhade, M. F. (2020). Challenges and Opportunities of Expansion of Islamic Banks in Ethiopia: Case of Commercial Bank of Ethiopian Dire Dawa Interest Free Branch. Research Journal of Finance and Accounting, 11(3), 34-42.

Abedifar, P., Ebrahim, S. M., Molyneux, P., \& Tarazi, A. (2015). Islamic banking and finance: Recent empirical literature and directions for future research. Journal of Economic Surveys, 29(4), 637-670.

Afzal-ur-Rahman, M. A. (1974). Economic Doctrines of Islam. Islamic Publication. Lahore, Pakistan. 
Agoston, G., \& Masters, B. (2009). Encyclopedia of the Ottoman Empire. Facts on File, Inc. An imprint of InfoBase Publishing. New York.

Alam, N., Gupta, L., \& Shanmugam, B. (2017). Islamic finance: A practical perspective. Springer.

Alharbi, A., (2015). Development of the Islamic Banking System. Journal of Islamic Banking and Finance, 3(1), 12-25.

Al-Hashimi, M., A., 2012: Ethiopian Muslims and the Ahbash controversy. Retrieved from https://crescent.icit-digital.org/articles/ethiopian-muslims-and-theahbash-controversy

Ali, A. S. (2020). Islamic micro finance services in Ethiopia: performances and implications for financial inclusion and poverty alleviation. International Journal of Commerce and Finance, 6(2), 159-169.

Ali, A. S., Bushera, I., \& Yesuf, A. J. (2020). The potential of Islamic financial institutions in promoting small and medium enterprises (SMEs) in Ethiopia. Journal of Economics and Political Economy, 7(3), 188-203.

Aman, A. (2019). Interest free window banking and finance in Ethiopia: inception to expansion. Journal of economic library, 6(4), 1-14.

Aman, A. W., Ali, A. S., \& Yesuf, A. J. (2021). The potential critical success factors of full-fledged interest-free banks in Ethiopia. Journal of Economics Bibliography, 7(4), 211-230.

Auda, J. (2008). Maqasid al-Shariah as philosophy of Islamic law: a systems approach. International Institute of Islamic Thought (IIIT).

Ayub, M. (2007). Understanding Islamic finance. John Wiley \& Sons Ltd, The Atrium, Southern Gate, Chichester.

Belayneh, Z. (2020). Opportunities and challenges of Islamic Banking Establishment in Ethiopia. Unpublished master's thesis, St. Mary's University, Ethiopia, Addis Ababa.

Chachi, A. (2005). Origin and development of commercial and Islamic banking operations. Journal of King Abdulaziz University: Islamic Economics, 18(2).

Demirgüç-Kunt, A., Leora K., Dorothe S., Saniya A., \& Jake H. (2018). The Global Findex Database 2017: Measuring Financial Inclusion and the Fintech Revolution. World Bank: Washington, DC.

Dhaoui, E. (2015). The role of Islamic Microfinance in Poverty Alleviation: Lessons from Bangladesh Experience. Tunisan Institute for Competitiveness and Quantitative Studies: MPRA Paper No. 63665. 
Feyissa, D. (2012). The transnational politics of the Ethiopian Muslim diaspora. Ethnic and Racial Studies, 35(11), 1893-1913.

Getachew, A. \& Kedir, S. (2019, May). Ethiopian PM attends iftar with Muslim community: Abiy Ahmed promises grand mosque, interest-free banking for Muslims. Anadolu Agency. Retrieved from https://www.aa.com.tr/en/africa/ethiopianpm-attends-iftar-with-muslimcommunity/1484949

Gill, P., Stewart, K., Treasure, E., \& Chadwick, B. (2008). Methods of data collection in qualitative research: interviews and focus groups. British dental journal, 204(6), 291-295.

Global Islamic Finance Report-GIFR (2020). An overview of the global Islamic financial services industry.

Hailu, S. M., \& Bushera, I. (2020). Interest Free Banking in Ethiopia: Prospects and Challenges. International Journal of Islamic Economics and Finance Studies, 6(2), 119-137.

Hailu, S. M., Kapusuzoglu, A., \& Ceylan, N. B. (2019). The Role of Islamic Financial Product Innovation in Reduction of Financial Exclusion in Ethiopia. In Handbook of Research on Managerial Thinking in Global Business Economics (pp. 426-446). IGI Global.

Htay, S. N. N., \& Zaharin, H. R. (2012). Critical Analysis on the Choice of Takaful (Islamic Insurance) Operating Models in Malaysia. World Journal of Social Sciences, 2(2), 112-127.

Iqbal, M., Ahmad, A., \& Khan, T. (1998). Challenges facing Islamic banking (Vol. 1). Jeddah: Islamic Research and Training Institute.

Iqbal, Z., \& Mirakhor, A. (2011). An introduction to Islamic finance: Theory and practice (Vol. 687). John Wiley \& Sons.

Islahi, A. A. (2007). Thirty years of research in the history of Islamic economic thought: Assessment and future directions. Islamic Economics Research Center, Jeddah.MPRA Paper No. 18102, pp. 347-370.

Islamic Financial Services Board -IFSB (2020). Islamic Financial Services Industry Stability Report. Kuala Lumpur, Malaysia, July.

Karbhari, Y., Naser, K., \& Shahin, Z. (2004). Problems and challenges facing the Islamic banking system in the west: The case of the UK. Thunderbird International Business Review, 46(5), 521-543.

Karimi, A. J. (2007). Challenges facing Islamic banks. Dawn Media Group. 
Malaysia International Islamic Finance Center -MIFC. (2015). Islamic Finance: Prospects and Challenges. Retrieved https://www.mifc.com/index.php?ch=28\&pg=72\&ac=139\&bb=uploadpdf

Mohamad, M. T., Abdullah, M. Y., Mohamad, M. A., \& Abidin, U. Z. A. A. Z. (2013). The historical development of modern Islamic banking: A study in South-east Asia countries. African Journal of Business Management, 1(1), 1-14.

Mohd Zamil, N. A. (2014). An empirical investigation into the problems and challenges facing Islamic banking in Malaysia. Cardiff University. (Doctoral dissertation, Cardiff University).

Nagaoka, S. (2012). Critical overview of the history of Islamic economics: formation, transformation, and new horizons. Asian and African area studies, 11(2), 114-136.

Nyazee, I. A. K. (2016). Outlines of Islamic jurisprudence (6 $6^{\text {th }}$ ed.) Advanced Legal Studies Institute. Islamabad, Pakistan.

Obaidullah, M. (2005). Islamic financial services. Jeddah: King Abdulaziz University Press. Saudi Arabia.

Obaidullah, M., (2008). Introduction to Islamic Microfinance. New Delhi: International Institute of Islamic Business and Finance.

Ökte, M. (2010). Fundamentals of Islamic economy and finance: theory and practice. Electronic Journal of Social Sciences, 9(31), 180-208.

Pasha, A. T., \& Hussain, M. M. (2013). Takaful Business Models: A Review, a Comparison. Business Management Dynamics, 3(4), 24-32.

Philips, A. A. B. (2006). The Evolution of Fiqh: Islamic Law and The Madhhabs. Riyad: International Islamic Publishing House.

Sefiani, Z., (2014). Policy Analysis on Ethiopia Interest Free Banking (IFB) Directive. Prepared for Mercy Corps.

Shanmugam, B., \& Zahari, Z. R. (2009). A primer on Islamic finance. The Research Foundation of CFA Institute.

Sole, J. A. (2007). Introducing Islamic banks into conventional banking systems. IMF Working Paper, WP/07/175.

Swartz, N. P., \& Coetzer, P. (2010). Takaful: An Islamic insurance instrument. Journal of Development and Agricultural Economics, 2(10), 333-339. 
Tiby, E., Mohamed, A., \& Grais, W. (2015). Islamic Finance and Economic Development: Risk Management, Regulation, and Corporate Governance. John Wiley and Sons.

Uddin, M. A. (2015). Principles of Islamic Finance: Prohibition of Riba, Gharar and Maysir.MPRA Paper No. 67711.

Zamzam Bank (2012). Zamzam bank under formation work report. Addis Ababa.

\section{Copyrights}

Copyright for this article is retained by the author(s), with first publication rights granted to the journal. This is an open-access article distributed under the terms and conditions of the Creative Commons Attribution license (http://creativecommons.org/licenses/by/4.0). 